\title{
Polscy mistrzowie teatru w Chinach
}

\begin{abstract}
Abstrakt
Celem artykułu jest prezentacja wybranych aspektów współpracy teatralnej pomiędzy Polską a Chinami, w szczególności zaś recepcja w Kraju Środka postaci takich jak Jerzy Grotowski i Krystian Lupa.
\end{abstract}

Słowa kluczowe: teatr, performatyka, Chiny, Polska, Krystian Lupa, Jerzy Grotowski, mistrz.

\section{Polish Masters of Theatre in China}

\begin{abstract}
The aim of this article is to present aspects of a theatrical co-operation between Poland and China, in particular the reception in the Middle Kingdom of characters such as Jerzy Grotowski and Krystian Lupa.
\end{abstract}

Keywords: theatre, performance studies, China, Poland, Krystian Lupa, Jerzy Grotowski, masters.

O ile do opinii publicznej w Polsce z pewnością przebiła się wiadomość, że Chińska Republika Ludowa stała się (prawie) największą gospodarką świata, o tyle wciąż chyba nie jest wystarczająco znana skala rozwoju w dziedzinie badań naukowych i inwestycji w kulturę. Gościłem w lipcu 2019 r. na corocznym kongresie International Federation for Theatre Research (IFTR), który odbywał się w Szanghaju, a ściślej w kampusie tamtejszej Akademii Teatralnej (STA), pod hasłem Theatre, Performance, and Urbanism. Nie muszę pisać, dlaczego właśnie Azja jest najlepszym miejscem do refleksji nad rozwojem megamiast, samą aglomerację szanghajską zaludnia ponad 20 milionów ludzi. Szanghaj jest większy niż sam Nowy Jork, co więcej - ma właśnie „nowojorskie” ambicje stania się jedną ze stolic globalnego świata.

* Uniwersytet Mikołaja Kopernika w Toruniu, Katedra Kulturoznawstwa. 
Interesujące jest chińskie podejście do teatru i nauk o teatrze (zarówno tradycyjnej teatrologii, jak i performatyki, a także ścieżek takich jak applied theatre, czyli formy teatralne i performatywne używane do rozwiązywania różnorakich problemów społeczności lokalnych). Nie da się ukryć, że teatr jako instytucja o proweniencji zachodniej nigdy nie należał do priorytetów chińskiej polityki kulturalnej po II wojnie światowej. Odium niepotrzebnej rozrywki, skazanej na zapomnienie, dotknęło w czasie rewolucji kulturalnej także rodzime formy sceniczne, zwłaszcza widowiskową operę pekińską. Szczęśliwie ten czas chińska kultura ma już za sobą. Otwarcie na świat zadekretowane przez rządzącą partię komunistyczną dotyczy także obszaru sztuki i kultury. Po tym, jak Chińczycy rozwiązali problemy podstawowej egzystencji obywateli, przyszedł czas na potrzeby wyższego rzędu, np. obcowania ze sztuką, w tym także i te w sferze sztuk scenicznych.

Podczas wspomnianego kongresu IFTR niezwykle pouczające było wystąpienie jednego z keynote speakers. Prezydent Shanghai Theatre Academy, prof. Huang Changyong, wychodząc od historii budynków teatralnych w swoim mieście, pokazał rozmach budowlany obecnych władz municypalnych i krajowych dążących do uczynienia z Szanghaju chińskiej stolicy sztuk performatywnych.

Architektura nowych chińskich teatrów zapiera dech w piersiach, ale każdemu europejskiemu humaniście nasuwa się pytanie o ludzki element tej hiperszybkiej metamorfozy. Jest to pytanie o kulturę teatralną - zarówno po stronie twórców, jak i odbiorców przedstawień, a także pytanie o model instytucjonalny teatru i estetyki, które korespondowałyby z nowoczesnością.

Miałem okazję oglądać w Chinach niewiele przedstawień, podczas tego pobytu jedno, za to uświadamiające, jak daleka jest jeszcze droga w tym kraju do zbudowania teatru artystycznego. To jedno przedstawienie było sprawnie wyprodukowaną i sprzedaną do Chin przez agencję z Broadwayu muzyczną opowieścią o Edith Piaf, wykonaną przez francuską aktorkę i zespół muzyczny z Paryża. Spektakl wypełnił miły wieczór w Majestic Theatre, jednym z nielicznych budynków, który przetrwał wojnę i czasy rewolucyjne, a dziś lokuje się na eleganckiej ulicy zdominowanej przez wieżowce i ekskluzywne sklepy. Bilety nie są tanie, teatr dba o obyczaje, zakazując jedzenia i picia na widowni, można powiedzieć, że teatr jest tu formą przyjemnej rozrywki dla klasy średniej - w sporej części młodych ludzi. I tu dochodzimy do sedna mojego tekstu, do odpowiedzi na pytanie, co my Polacy mamy do zaoferowania naszym chińskim partnerom w domenie teatru i sztuk performatywnych?

Zacząć należy od kwestii instytucjonalnych. Współpraca Wydziału Filologicznego (od 1 października 2019 r.) Uniwersytetu Mikołaja Kopernika z Akademią Teatralną w Szanghaju (STA) zaczęła się na dobre latem 2017 r. To, że czas biegnie szybko uświadomiłem sobie, biorąc w ręce świeżo wydaną publikację, zawierającą referaty wygłoszone na sympozjum poświęconym teatrologii na świecie i w Chinach ${ }^{1}$.

\footnotetext{
${ }^{1}$ Gong Baorong (red.) (2018) Shijie xiju xueke fazhan baogao. Guoji xiyu zhong da xiju xue, Shanghai Jiao Tong University Press, Szanghaj.
} 
Myśl ta przyszła mi do głowy w lipcu 2019 r., kiedy siedziałem w towarzystwie naszego głównego chińskiego partnera - prof. Baoronga Gonga w niedużej siedzibie Centrum Badania Teatru Europy Wschodniej, które wspólnie otworzyliśmy rok wcześniej podczas międzynarodowej konferencji From Jerzy Grotowski to Krystian Lupa - on the Influence of Polish Theatre in the World. Otwarcie tej konferencji było niezwykle uroczyste: przemawiali obok gospodarzy także polscy przedstawiciele - wicekonsul Anna Romsicka z polskiej placówki dyplomatycznej w Szanghaju i prodziekan Wydziału Filologicznego UMK dr Adam Kola. Potem odbyło się dwugodzinne spotkanie z Krystianem Lupą, otwierające konferencję, podczas której referenci z Polski i Chin, a także przedstawiciele uczelni z akademii teatralnej z Sofii, prof. Kalina Stefanova, oraz uniwersytetu w Sibiu (Rumunia), prof. Ion Tomus, prezentowali różne aspekty polskiego teatru współczesnego, tzn. teatru XX w.

Już na etapie ustalania tematu tego naukowego spotkania dla obu stron stało się jasne, że musimy szukać pola wspólnego i że tym polem muszą się stać wielkie postaci polskiego teatru znane na całym świecie. Akurat w wieku XX jest tych wybitnych artystów wielu, jednak z chińskiej perspektywy prawdziwymi mistrzami polskiego teatru okazują się Jerzy Grotowski i Krystian Lupa.

Przypadek Lupy odsłania pewne paradoksy promocji naszej kultury na świecie. Boom teatralny $w$ Chinach, licznie i $z$ rozmachem rozwijające się festiwale teatralne (poza Pekinem i Szanghajem m.in. w Wuzhen i Wuhan) z budżetami, które pozwalają zaprosić dowolny zespół na świecie, otworzyły także możliwość występów gościnnych polskich artystów. Teatr polski stał się rozpoznawalny w Chinach dzięki metodycznej pracy Instytutu Adama Mickiewicza w ramach „Programu Azja”. Wsparcie finansowe i organizacyjne IAM sprawiło, że chińska widownia mogła obejrzeć spektakle Grzegorza Jarzyny, Jana Klaty czy Pawła Passiniego, a nawet wielogodzinne Dziady Michała Zadary oraz przedstawienia teatrów alternatywnych takich jak Pieśń Kozła czy Dada von Bzdülöw. Tylko jednak Krystian Lupa przebił się mocniej, pokonując znaczną konkurencję zachodnioeuropejską czy amerykańską ${ }^{2}$. Jego Wycinka ukazująca ironicznie współczesnych artystów pozwoliła znaleźć wspólny język z chińską widownią, która odnosiła kwestie podnoszone w spektaklu do sytuacji aktorów czy reżyserów we własnym kraju.

Owoce występów zespołu Krystiana Lupy w Chinach mogą być różnorakie. Przede wszystkim reżyser jest tam zapraszany do współpracy przy tworzeniu nowych spektakli, zrealizował już w Pekinie swój pierwszy spektakl z udziałem chińskich aktorów zatytułowany Mo Fei (z tekstem Lie Tieshenga). Został także zaproszony do pracy ze studentami STA.

Swoją drogą na chińskich odbiorców działa także magia określenia „uczeń Lupy". Jeden z tych uczniów, Grzegorz Jarzyna zdążył zrealizować w Chinach spektakl pt. Dwa miecze na przełomie 2017 i 2018 r. Jarzyna wybrał starą legendę chińską

\footnotetext{
2 Półżartem, półserio można powiedzieć, że reżyser kultowej Wycinki według powieści Thomasa Bernharda i równie wybitnej Persony. Marylin, portretującej ikonę zachodniej popkultury Marylin Monroe, ma po prostu niezwykle chińskie nazwisko Lu Pa.
} 
z IV w., w której finale, mówiąc obrazowo, król zostaje poddany karzącemu mieczowi sprawiedliwości. Spektakl napotkał na problemy z cenzurą, premiera była zagrożona, w końcu jednak do niej doszło w Pekinie. Jak mówił w wywiadach sam Jarzyna ${ }^{3}$, teatr polski jest odbierany w Chinach jako niezwykle emocjonalny, otwarty w tej sferze, którą chińska kultura blokuje w życiu codziennym. Jak pokazuje przykład Dwóch mieczy, nasz teatr jest także odbierany jako metaforyczny i nasycony aluzjami, które nieoczekiwanie mogą nabierać ciężaru politycznego.

Z akademickiego punktu widzenia po licznych występach polskich artystów teatru w Chinach otworzyło się pole refleksji nad polskim teatrem po $1945 \mathrm{r}$. Na przykład spektakle Krystiana Lupy oparte często na erudycyjnej literaturze pisarzy niemieckojęzycznych, (psycho)analityczne, nowoczesne, odważne w ich estetyce teatralnej wykorzystującej cielesność aktorów, wymagają użycia języka nowej teatrologii i performatyki, ujęć inter- i transdyscyplinarnych. To, że chińscy teatrolodzy nie są, póki co, właściwie przygotowani do ich odbioru, pokazały referaty prezentowane na naszej konferencji. O ile naukowcy z Tajwanu czy Hongkongu wydają się dobrze zorientowani w estetykach współczesnego teatru, obracają się zresztą w kręgu artystów uprawiających popularny dziś na Zachodzie Europy i w USA physical theatre, teatr antropologiczny czy teatr postdramatyczny, o tyle, jak sądzę, uczeni z Chin kontynentalnych niezupełnie jeszcze czują ducha nowoczesnego teatru. Osobna i zupełnie poważna sprawa to konteksty kulturowe, w które wpisany jest polski teatr. Co prawda w Chinach ukazał się przekład nowatorskiej książki Dariusza Kosińskiego Teatra polskie. Historie, z moich obserwacji wynika jednak, że wymagałaby ona swoistych dopowiedzeń, komentarzy i metakomentarzy dla czytelnika obcojęzycznego, a tym bardziej chińskojęzycznego, gdzie bariery układają się na linii odmiennej historii, kultury i wrażliwości estetycznej.

Jerzy Grotowski, pierwszy z mistrzów teatru polskiego, którego umieściliśmy $\mathrm{w}$ tytule naszej konferencji, to nieco odmienny od Lupy casus. Uznana wielkość międzynarodowa, nieżyjący guru teatru ubogiego, parateatru, Teatru Źródeł czy Sztuki jako Wehikułu, jest znany chińskim badaczom właściwie tylko z pierwszej fazy jego działalności, w Opolu i Wrocławiu. Wygląda to trochę tak, jakby wszyscy badacze jego twórczości szli tropem jedynego tomu tekstów Grotowskiego przełożonego na chiński. Nie znają oczywiście najnowszych polskich badań, ale część nowych książek Leszka Kolankiewicza, Dariusza Kosińskiego i Grzegorza Ziółkowskiego funkcjonuje tylko po polsku. Jak wiele jest do zrobienia, widać w faktach: konferencja From Jerzy Grotowski to Krystian Lupa była pierwszą w Chinach (sic!) konferencją poświęconą polskiemu teatrowi. Jak dotąd w Kraju Środka ukazało się kilkanaście (sic!) artykułów poświęconych polskiemu teatrowi. Tym większe

\footnotetext{
${ }^{3}$ Grzegorz Jarzyna: Wystawiam spektakl „Dwa miecze” w Chinach, Mam zgodę cenzury, „Duży Format” 15 stycznia 2018, https://wyborcza.pl/duzyformat/7,127290,22884955,grzegorz-jarzyna-wystawiamspektakl-dwa-miecze-w-chinach.html; Grzegorz Jarzyna o spektaklu „Dwa miecze” mówi Jackowi Cieślakowi, „Rzeczpospolita” online, 18 stycznia 2018, https://www.rp.pl/Teatr/301189927-GrzegorzJarzyna-o-premierze-spektaklu-Dwa-miecze-w-Pekinie.html
} 
znaczenie ma to, że nasi chińscy koledzy z prof. Gongiem na czele gotowi są wypełniać intensywnie te luki w transferze wiedzy. Zaczęliśmy na razie od publikacji pokonferencyjnych, w przygotowaniu do druku są dwutomowa antologia współczesnego dramatu Europy Wschodniej oraz antologia polskiego dramatu współczesnego (z akcentem na mistrzów: Witkacego, Różewicza, Gombrowicza i Mrożka). Centrum Badania Teatru Europy Wschodniej przy Shanghai Theatre Academy wzbogaciło się ostatnio o kilkadziesiąt nagrań DVD z przedstawieniami polskiego teatru i ekranizacjami dramatów - dar Wydziału Filologicznego UMK. Znaleźliśmy się tam zresztą w bardzo dobrym sąsiedztwie, tuż obok mieści się Centrum Marvina Carlsona, nestora amerykańskiej teatrologii, jednego z prekursorów performatyki. Jeśli uda nam się utrzymać intensywność kontaktów, z pewnością chińscy studenci aktorstwa i reżyserii oraz badacze teatru poznają lepiej dziedzictwo teatralne naszej części Europy.

Póki co w czasie wspomnianej konferencji udało nam się zarysować tematy przyszłej naukowej eksploracji - recepcję antyku w polskim teatrze, m.in. Krzysztofa Warlikowskiego (dr hab. Barbary Bibik, prof. UMK), twórczość Tadeusza Kantora (dr Marzenna Wiśniewska, UMK i dr Paweł Stangret, UKSW), nowe perspektywy metodologiczne: psychoanaliza Carla Gustava Junga (tak spektakl Krystiana Lupy Persona analizowała prof. Krystyna Duniec, IS PAN), studia postkolonialne (dr Adam Kola o postkolonialnych uwikłaniach twórcy Teatru Laboratorium w fazie Teatru Źródeł) czy performatyka (referat dra hab. Artura Dudy, prof. UMK, o aktorstwie cielesno-performatywnym w twórczości Grotowskiego i Lupy).

Już na wiosnę 2020 r. odbędzie się na Uniwersytecie Mikołaja Kopernika kolejna edycja Festiwalu „Za kulisami. Toruńskie spotkania wokół dramatu”, pomyślanego jako biennale skoncentrowane na twórczości dramatycznej z wybranego kręgu językowego. Tym razem będzie to edycja poświęcona dramaturgii chińskojęzycznej. 